\title{
Arteria iliaca aneurysma nyitott és endovascularis kezelése
}

\author{
Garbaisz Dávid dr. ${ }^{1,2}$ - Boros András dr. ${ }^{1}$ \\ Legeza Péter dr. ${ }^{1,2}$. Szeberin Zoltán dr. ${ }^{1,2}$
}

Semmelweis Egyetem, Általános Orvostudományi Kar, 'Városmajori Szív- és Érgyógyászati Klinika, ${ }^{2}$ Érsebészeti Tanszék, Budapest

\begin{abstract}
Bevezetés és célkitüzés: Az arteria iliaca aneurysmák az összes aneurysmák 2\%-át teszik ki. Optimális kezelésük nem egyértelmú, sebészi kezelésük eredményeiről alig áll rendelkezésre hazai adat. Célkitűzésünk volt az arteria iliaca aneurysma miatt operált betegek mortalitásának és perioperatív morbiditásának elemzése, valamint az elektív nyitott mütéten és stentgraft-implantáción (EVIAR) átesett betegcsoportok eredményeinek összehasonlítása.

Módszer: Egy intézményben 2005. január 1. és 2014. december 31. között arteria iliaca aneurysma miatt mútéten átesett betegek retrospektív vizsgálata.

Eredmények: Tíz év alatt 62 betegnél végeztünk elektív mútétet arteria iliaca aneurysma miatt (54 férfi [87,1\%]). A betegek átlagéletkora 68,9 év (19-89 év) volt. Tíz esetben végeztünk akut mütétet aneurysma ruptura miatt (13,9\%), ezek közül 3 beteg halt meg a perioperatív időszakban (30\%). Az anatómiai lokalizációt tekintve többségében az arteria iliaca communison $(80,6 \%)$ alakult ki értágulat. Elektív beavatkozásként nyitott mútétet 35 esetben $(56,5 \%)$, EVIAR-t 25 esetben $(40,3 \%)$, egyéb endovascularis intervenciót 2 esetben $(3,2 \%)$ végeztünk. A posztoperatív szövődmény ( 1 fö $[4,0 \%]$ vs. 17 fó $[48,5 \%] ; p<0,001$ ) és az intenzív osztályos kezelés [29 fö $(82,8 \%)$ vs. 2 fó $(8,0 \%) ; \mathrm{p}<0,001]$ szignifikánsan ritkább EVIAR-t követően, mint nyitott mútét esetén. Továbbá szignifikánsan kevesebb a posztoperatív kórházi ápolási napok száma $(4,7 \pm 2,3$ nap vs. $11,8 \pm 12,2$ nap; $\mathrm{p}=0,006)$ és a transzfúziós igény (1 fó $[4,0 \%]$ vs. 26 fó $[74,2 \%] ; \mathrm{p}<0,001)$ EVIAR végzése során. A hosszú távú túlélési arány a két módszer között nem különbözött jelentős mértékben (81,4\% vs. 71,4\%; p = 0,95).

Következtetés: Az arteria iliaca tágulat sebészi kezelésének szükségessége esetén, alacsonyabb szövődményrátája és kórházi ápolásigénye miatt, az endovascularis mútétet ajánljuk elsősorban.
\end{abstract}

Orv Hetil. 2018; 159(13): 520-525.

Kulcsszavak: arteria iliaca aneurysma, nyitott műtét, endovascularis, stentgraft

\section{Open and endovascular repair of iliac artery aneurysms}

Introduction and aim: Iliac artery aneurysms make up $2 \%$ of all aneurysms. There are only a few data available on the results of surgical treatment, therefore the optimal treatment is unclear. Our objective was the retrospective analysis of the perioperative morbidity and mortality of patients who underwent iliac artery surgery as well as the comparison of elective open surgery and endovascular iliac aneurysm repair (EVIAR).

Method: Retrospective analysis of patients who underwent surgery for iliac artery aneurysm between 1 January 2005 and 31 December 2014.

Results: During the 10-year period, 62 patients with a mean age of 68.9 years underwent elective surgery for iliac artery aneurysm (54 males, $87.1 \%$ ). In 10 cases acute surgery was performed due to aneurysm ruptures (13.9\%), 3 patients died within the perioperative period (30\%). Regarding anatomical localisation, aneurysm developed mostly on the common iliac artery $(80.6 \%)$. As an elective surgery, 35 patients $(56.5 \%)$ underwent open surgery, $25(40.3 \%)$ underwent EVIAR and other endovascular interventions were performed in 2 cases (3.2\%). Postoperative complications ( 1 patient $[4.0 \%]$ vs. 17 patients $[48.5 \%] ; \mathrm{p}<0.001)$ and intensive care treatment $(29$ patients $[82.8 \%]$ vs. 2 patients $[8.0 \%] ; \mathrm{p}<0.001)$ were significantly rarer after EVIAR than after open surgery. Furthermore, EVIAR resulted in considerably shorter postoperative hospital stays $(4.7 \pm 2.3$ days vs. $11.8 \pm 12.2$ days; $\mathrm{p}=0.006)$ and significantly less blood transfusion demand ( 1 patient [4.0\%] vs. 26 patients [74.2\%]; $\mathrm{p}<0.001$ ). There were no significant differences regarding long-term survival rates between EVIAR and open surgery $(81.4 \%$ vs. $71.4 \% ; \mathrm{p}=0.95)$. Conclusion: In case of the surgical treatment of iliac artery aneurysms, owing to the lower complication rates and shorter postoperative length of stay, EVIAR is primarily recommended. 
Keywords: iliac aneurysm, vascular surgical procedures, vascular grafting

Garbaisz D, Boros A, Legeza P, Szeberin Z. [Open and endovascular repair of iliac artery aneurysms]. Orv Hetil. 2018; 159(13): 520-525.

(Beérkezett: 2017. október 19.; elfogadva: 2017. november 12.)

\section{Rövidítések}

$\mathrm{AAA}=$ abdominalis aorta aneurysma; $\mathrm{a} .=$ arteria AIC $=$ a. ili aca communis; $\mathrm{AIE}=\mathrm{a}$. iliaca externa; $\mathrm{AII}=\mathrm{a}$. iliaca interna; EVIAR $=$ endovascular iliac aneurysm repair $;$ CTA $=$ CT-angio gráfia

$\mathrm{Az}$ arteria iliaca aneurysma ritka érbetegség. Az esetek 20\%-ában abdominalis aorta aneurysmával (AAA) együtt jelenik meg; izolált formában az intraabdominalisan megjelenő aneurysmák kevesebb mint 6-7\%-át teszik ki [1]. Az esetek jelentős hányadában aszimptomatikus megjelenésű [2], azonban súlyos szövődményekhez vezethet, pl. ruptura, distalis embolisatio, thrombosis, valamint visceralis, vascularis, ureter vagy neurológiai kompressziós tünetek. Etiológiai faktorai megegyeznek az AAA okaival, melyek szerint előfordulhat fóként atherosclerosis, de trauma, infekció vagy genetikai eltérés talaján kialakuló kötőszöveti betegség következményeként is [1]. Az iliaca aneurysma legsúlyosabb szövődménye az aneurysma ruptura, melynek a perioperatív mortalitása elérheti akár a 40\%-ot [3]. A helyesen megválasztott sebészi kezelés időpontja és technikája alapvetően meghatározza a betegség kimenetelét.

Az iliaca aneurysma érsebészeti kezelését a nyitott mútét vagy az endovascularis mútét jelenti, az eredményekről azonban kevés adat áll rendelkezésre. A perioperatív halálozás, a korai és késői szövődmények, a posztoperatív ápolási időtartam vonatkozásában az endovascularis módszerek közé tartozó stentgraftbeültetés (EVIAR) alkalmazása javulást eredményezhet.

Célkitűzésünk volt egy egyetemi centrum érsebészetén 10 év alatt arteria iliaca aneurysmával diagnosztizált és operált betegek anyagának, perioperatív eredményeinek retrospektív vizsgálata, illetve az elektív nyitott mütéten és EVIAR-on átesett betegcsoportok eredményeinek összehasonlítása.

\section{Módszer}

A Semmelweis Egyetem Városmajori Szív- és Érgyógyászati Klinikáján 2005. január 1. és 2014. december 31. között arteria iliaca aneurysmával diagnosztizált és operált betegek anyagának retrospektív vizsgálatát végeztük a Medsol számítógépes rendszer és a kórlapadatok elemzése alapján. Vizsgálati anyagunkban minden, az arteria iliaca ágrendszerén (communis, externa, interna) előforduló aneurysmát figyelembe vettünk. Az aneurysma lokalizációjának és átmérőjének megítéléséhez, valamint a pontos mútéti terv felállításához minden esetben CT-angiográfia (CTA) került elvégzésre (1. ábra). Az elektív mútéti indikációt $\mathrm{a} \geq 3 \mathrm{~cm}$-es aneurysmaátmérő jelentette [4].

Az alkalmazott mütéti módszerről az operáló sebész, illetve a klinikánkon múködő multidiszciplináris szakmai csoport (érsebész, intervenciós radiológus) döntött. A mútéti típus megválasztásában szerepet játszottak az anatómiai jellemzők, a beteg általános állapota, kora, illetve a mútét elektív vagy sürgősségi jellege. Nyitott mútét során transperitonealis vagy retroperitonealis behatolásból műérinterpositum-beültetést végeztünk. Endovascularis mútét esetén - néhány esetet kivéve (embolisatio, Amplatzer-behelyezés) - stentgraft-implantációt végeztünk, melynek során femoralis feltárásból katéteres

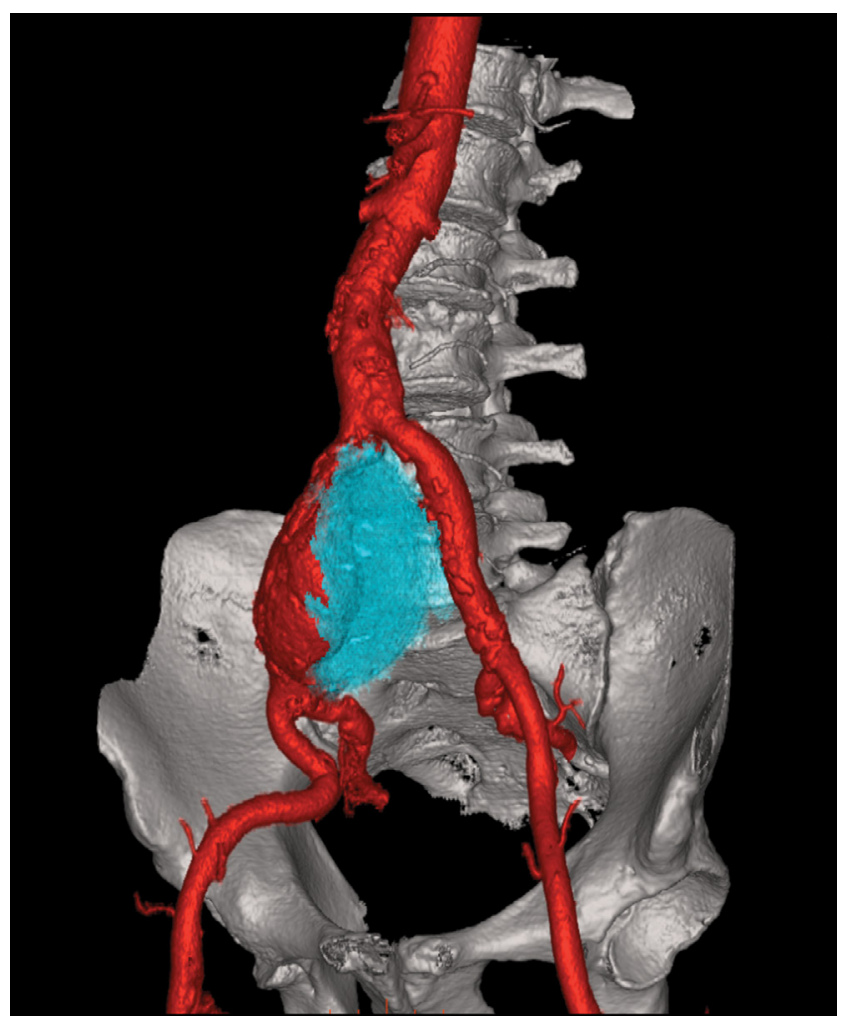

\begin{tabular}{l|l} 
1. ábra & A. iliaca communis izolált aneurysma CTA-rekonstrukciós képe
\end{tabular} Piros: intravascularis véráramlás; kék: aneurysma thrombus 
úton, röntgen képerősítő alatt került beültetésre a stentgraft.

$\mathrm{Az}$ adatok grafikus és statisztikai megjelenítése GraphPad Prism (GraphPad Software, Inc., La Jolla, CA, USA) szoftver segítségével történt. Student-féle t-próbát, Fisher-féle egzakt-próbát és Kaplan-Meier-féle túlélés-analízist alkalmaztunk. Az átlagértékek közötti különbségeket $\mathrm{p}<0,05$ konfidenciaintervallum esetén értékeltük szignifikáns különbségként.

Munkánkat a Semmelweis Egyetem Regionális, Intézményi Tudományos és Kutatásetikai Bizottsága által kiadott 92/2017. számú engedély alapján végeztük. Adatkezelési és feldolgozási tevékenységünk során maradéktalanul figyelembe vettük az 1997. évi XLVII. törvény 21. $\$$-át az egészségügyi és a hozzájuk kapcsolódó személyes adatok kezeléséről és védelméről, valamint az információs önrendelkezési jogról és az információszabadságról szóló 2011. évi CXII. törvényt.

\section{Eredmények}

A vizsgált tízéves időszakban 62 beteg esett át elektív nyitott vagy endovascularis mútéten arteria iliaca aneurysma miatt. A betegek átlagéletkora 68,9 $\pm 10,9$ év volt. Döntő többségük férfi volt: $87,1 \%$ ( 54 fő). A mútéti beavatkozás típusa szerint nyitott mútétre 56,5\% (35 fó), EVIAR-ra 40,3\% (25 fó), egyéb endovascularis intervencióra 3,2\% (2 fö) arányban került sor.

$\mathrm{Az}$ elektív esetek mellett, aneurysma ruptura miatt végzett akut mútét 10 esetben $(13,9 \%)$ fordult elő, közülük 3 beteg a közvetlen posztoperatív időszakban meghalt (30\%). A rupturált aneurysma miatt sürgős mütétre került betegek között 7 esetben (70\%) nyitott mütétet, 2 esetben (20\%) EVIAR-t, 1 esetben (10\%) pedig egyéb endovascularis intervenciót végeztünk. Egy beteg nyitott mütétet, l beteg EVIAR-t, l beteg pedig embolisatio és Amplatzer-behelyezést követően halt meg.

Az elektív esetek perioperatív eredményeinek összehasonlítása során, nyitott mütét esetén a férfiak aránya 85,7\% (30 fó), míg az EVIAR-ra került betegek között 88,0\% (22 fo) volt. Az átlagéletkor nyitott mütét végzése esetén 68,4 $\pm 8,3$ év, EVIAR során $67,9 \pm 13,6$ év volt $(\mathrm{p}=0,86)$.

A fö cardiovascularis perioperatív rizikófaktorok közül a coronariabetegség megjelenése szignifikánsan magasabbnak bizonyult nyitott mütét esetén $(\mathrm{p}=0,004)$. A hypertonia, a hyperlipidaemia és a cukorbetegség vonatkozásában nem mutatkozott szignifikáns különbség a nyitott mútétre, illetve EVIAR-ra került betegek között (1. táblázat).

Anatómiai elhelyezkedése szerint az arteria iliaca aneurysma 80,6\%-ban (50 fó) az a. iliaca communison (AIC), 9,6\%-ban (6 fó) az a. iliaca internán (AII), míg ritkán, 1,6\%-ban (1 fó) az a. iliaca externán (AIE) fordult elő. A nyitott mütétre és EVIAR-ra került betegek között az anatómiai lokalizációt tekintve szignifikáns kü-
1. táblázat | Cardiovascularis kísérőbetegségek

\begin{tabular}{llll}
\hline $\begin{array}{l}\text { Cardiovascularis kíséróbe- } \\
\text { tegség }\end{array}$ & $\begin{array}{l}\text { Nyitott } \\
\text { mútét, n }(\%)\end{array}$ & $\begin{array}{l}\text { Stentgraft- } \\
\text { implantáció, } \\
\mathrm{n}(\%)\end{array}$ & p-érték \\
\hline Hypertonia & $24(68,5)$ & $14(56)$ & $\mathrm{NS} / 0,41$ \\
Hyperlipidaemia & $19(54,2)$ & $12(48)$ & $\mathrm{NS} / 0,79$ \\
ISZB/coronariabetegség & $18(51,4)$ & $7(28)$ & 0,004 \\
Diabetes mellitus & $10(28,5)$ & $2(8)$ & $\mathrm{NS} / 0,058$ \\
\hline
\end{tabular}

ISZB = ischaemiás szívbetegség; NS = nem szignifikáns

lönbség nem mutatkozott (nyitott mütét vs. EVIAR; AIC: $\mathrm{p}=0,72 ;$ AII: $\mathrm{p}=0,68$; AIE: $\mathrm{p}=0,42)$.

$\mathrm{Az}$ aneurysmák anatómiai jellemzői alapján beteganyagunk 66,1\%-ában (41 fó) izoláltan fordult elő iliaca aneurysma, AAA-val együtt 19,3\%-ban (12 fó) került leírásra. A nyitott mútétre került betegek között többször fordult elő a. iliaca aneurysma AAA-val együtt, mint az EVIAR-csoportban (10 fó $[28,5 \%]$ vs. 2 fö [8\%]; $p=$ $0,058)$.

$\mathrm{Az}$ aneurysma átlagos átmérője a nyitott mütéten átesett csoportban szignifikánsan nagyobbnak bizonyult az EVIAR-csoporthoz képest $(42,8 \pm 21,1 \mathrm{~mm}$ vs. 29,5 $\pm 17,2 \mathrm{~mm} ; \mathrm{p}=0,01)$.

Az elektív mútétre került 62 beteg közül 1 beteg halt meg mütéti szövődmények miatt ( $1,6 \%$-os perioperatív mortalitás).

Szignifikánsan több esetben észleltünk posztoperatív szövődményt nyitott mútétet követően, mint EVIAR esetén ( 17 fó $[48,5 \%]$ vs. 1 fó $[4,0 \%] ; \mathrm{p}<0,001)$. Intenzív osztályos kezelésre nyitott mütétet követően 29 fó $(82,8 \%)$, EVIAR-t követően 2 fó $(8,0 \%)$ esetén volt szükség $(\mathrm{p}<0,001)$. Az intenzív osztályon töltött napok száma szignifikánsan több volt a nyitott mútétben részesült betegcsoportban az EVIAR-on átesett betegekhez képest $(2,5 \pm 2,4$ nap vs. $0,1 \pm 0,2$ nap; $p<0,001)$.

A posztoperatív kórházi ápolási napok száma a nyitott mütétben részesült csoportban szignifikánsan magasabb volt, mint EVIAR-t követően $(11,8 \pm 12,2$ nap vs. $4,7 \pm$ 2,3 nap; $\mathrm{p}=0,006$ ).

A mütét alatti, illetve a mútétet követő transzfúziós igény nyitott mütéten átesett betegcsoportban szignifikánsan magasabb volt az EVIAR-on átesett betegekhez képest (26 fó [74,2\%] vs. 1 fó [4,0\%]; p<0,001).

A Kaplan-Meier-analízis alapján 5 éves utánkövetési időt vizsgálva nyitott mütétet követően alacsonyabb a túlélési arány $(71,4 \%)$ az EVIAR-hoz képest $(81,4 \%)$, mely azonban nem szignifikáns mértékü $(\mathrm{p}=0,95)$ (2. ábra).

\section{Megbeszélés}

Az izoláltan előforduló a. iliaca communis aneurysmák előfordulása minden aneurysmaticus megbetegedést tekintve mindössze 2\%-ra tehető [5], AAA-val együtt 2025\%-ban jelenik meg [1]. A fusiformis aneurysmák elek- 


\section{5 éves utánkövetés}

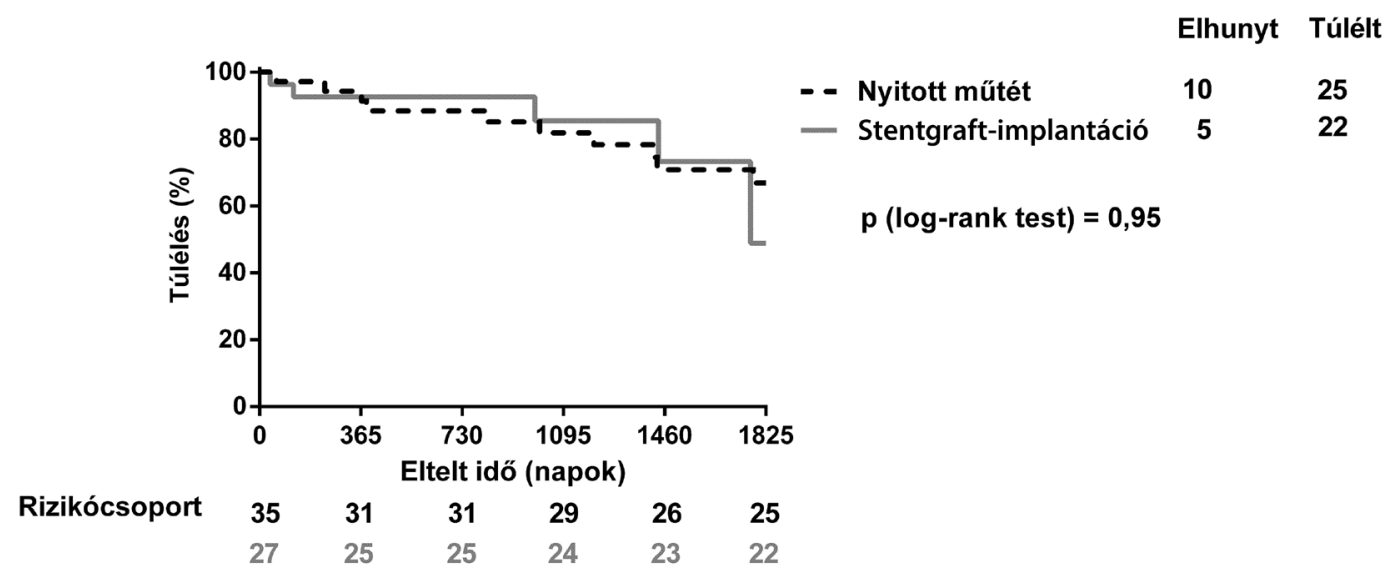

tív mütéti indikációjának általában a $3 \mathrm{~cm}$ maximális átmérőt tartjuk [6], kivéve, ha az értágulat tünetképző vagy nem valódi, illetve ha saccularis aneurysmáról van szó.

Mivel ritka aneurysmatípussal állunk szemben, egyértelmú ajánlás hiányában a mai napig nem egységes a kezelési módja ennek az aneurysmacsoportnak. Vizsgálatunk segítséget nyújthat az iliaca aneurysmák sebészi kezelésének helyes megválasztásában.

A két fó érsebészeti kezelési irányvonalat a nyitott mütét, illetve az EVIAR jelenti. Az anatómiai lokalizáció sajátosságaiból adódóan, nyitott mütét során a mélyen a medencében elhelyezkedő iliaca aneurysmák jelentős technikai és anatómiai kihívást jelentenek az operáló sebész számára, a betegeknek pedig számottevő posztoperatív mortalitással és morbiditással kell számolniuk. Az endovascularis megoldás fó nehézségét a sokszor az infrarenalis aortát, illetve az arteria iliaca internát is érintő tágulat megléte, valamint az arteria iliaca interna lehetőség szerinti megtartása jelenti.

Közleményünkben 10 éves időtartamot felölelő, klinikánk a. iliaca aneurysma miatt operált betegei anyagának retrospektív vizsgálati eredményeit mutatjuk be, mely vizsgálat hazánkban elsőként hasonlítja össze az elektíven végzett nyitott mütétre, illetve EVIAR-ra került betegcsoportokat.

Az a. iliaca aneurysma döntően idős férfiak körében fordul elő. Betegeink átlagéletkora megegyezik az irodalomban korábban közölt adatokkal. Chaer és mtsai [7] az izolált a. iliaca communis aneurysma nyitott és endovascularis mútéti kezelésének összehasonlításakor szintén erős férfidominanciáról és 70,5 éves átlagéletkorról számolnak be. Boules és mtsai [8] 93\%-os férfidominanciát és 75 éves átlagéletkort írtak le.

$\mathrm{Az}$ endovascularis módszerek az irodalmi adatoknak megfelelő arányban kerülnek alkalmazásra klinikánkon; Chaer és mtsai [7] 71 beteget felölelő vizsgálatában 73\%ban, Patel és mtsai [9] 56 beteget vizsgáló anyagában 57\%-ban végeztek endovascularis beavatkozást, azonban Laine és mtsai [10] az a. iliaca interna aneurysma mütéti adatainak összehasonlításakor 73\%-ban nyitott mútétről, 27\%-ban endovascularis beavatkozás végzéséről számolnak be egy multicentrikus vizsgálat során.

$\mathrm{Az}$ a. iliaca aneurysma átlagéletkori megjelenése a 7. és a 8. életévtized közé tehető, és szintén ebben az életkorban érik el előfordulási csúcsukat az olyan kíséróbetegségek, mint a hypertonia, a hyperlipidaemia, az ischaemiás szívbetegség és a cukorbetegség. A teljes vizsgált beteganyagunkban is jelentős mértékü a felsorolt megbetegedések előfordulása. Az alkalmazott két érsebészeti módszer között szignifikáns különbséget egyedül a coronariabetegség vonatkozásában találtunk a kísérőbetegségek között. Patel és mtsai [9], illetve több korábbi vizsgálatok [11-13] nem találtak különbséget a különböző kísérőbetegségek tekintetében a nyitott és az endovascularis mútét összehasonlításakor. Mind a nemzetközi irodalom, mind saját eredményeink arra engednek következtetni, hogy a sebészi kezelés megválasztásában nem játszik szerepet a kísérőbetegségek jelenléte.

Az iliaca aneurysmák anatómiai jellemzőinek vizsgálatakor a betegek csaknem kétharmadában izolált előfordulást regisztráltunk, ami ellentmond az irodalmi adatoknak, melyek szerint a leggyakrabban AAA-val együttes az előfordulás. Lawrence és mtsai [14] 10 éves periódust vizsgáltak, melyben számba vették az összes aneurysmával operált beteget az Amerikai Egyesült Államokban. Eredményeikben több mint 10 ezer beteg közül mindössze 1111 (11\%) betegnél fordult elő izolált a. iliaca aneurysma.

A mütétre került aneurysmák méretét vizsgálva nagyobbrészt a kisebb átmérővel rendelkező értágulatok kerülnek EVIAR-ra [9, 12], habár szignifikáns különbséget kevés vizsgálat közöl [7]. Eredményeink megegyeznek a korábban közölt adatokkal, az esetek jelentős hányadában a kisebb átmérő esetén választunk EVIAR-t. Az említett eredmények hátterében az aneurysma anató- 
miai jellemzői állnak, melyek technikailag kivitelezhetővé teszik EVIAR alkalmazását. Kisebb átmérő esetén nagyobb valószínűséggel jelenik meg izolált aneurysma csupán egy iliacaágat magában foglalva, ami technikailag lehetôvé teszi a stentgraftbeültetést, illetve az aneurysma megfelelő hosszúságú proximalis és distalis nyakkal rendelkezik a stentgraftbehelyezéshez.

A posztoperatív szövődményeket tekintve EVIAR-t követően szignifikánsan alacsonyabb mértékben jelennek meg szövődmények a nyitott mütéthez képest. Posztoperatív szövődménynek tekintettünk a mütéthez köthető minden szövődményt. Nyitott műtét esetén a leggyakrabban sebfertőzés, álaneurysma, retroperitonealis tályog, végtagi ischaemia, pulzáló haematoma, nyirokcsorgás, többszervi elégtelenség alakult ki, EVIAR-t követően pedig összesen egy esetben kellett mütéti konverzióként femorofemoralis crossover bypass mútétet végezni gyenge végtagi beáramlás miatt. Pitoulias és mtsai [12] két európai érsebészeti centrum a. iliaca aneurysmával kezelt betegeinek anyagán hasonlította össze a nyitott mütét és a stentgraft-implantáció eredményeit 8 éves periódust vizsgálva. Vizsgálatuk során az EVIAR alacsonyabb szövődményrátáját írták le, valamint Ferreira és mtsai [15], illetve Buck és mtsai [16] is hasonlóan kedvező eredményekről számoltak be.

Az intenzív osztályos kezelés szükségessége és hossza, valamint a posztoperatív kórházi ápolási napok száma fontos és megbízható markereknek tekinthetők a betegség kimenetele szempontjából, amennyiben két mútéti technikát hasonlítunk össze. Vizsgálatunkban EVIAR-t követően a fent említett jellemzők mindegyike szignifikánsan alacsonyabbnak bizonyult, ami a betegek kisebb mütéti megterhelését, gyorsabb felépülését, alacsonyabb posztoperatív szövődmény kockázatát jelenti. Korábbi vizsgálatok hasonlóan kedvező eredményekről számoltak be [7-9].

A perioperatív vörösvértest-transzfúzió számos kockázati tényezőt hordoz. Nem csupán önmagában az indikációként fellépő akut vérvesztés, illetve krónikus anaemia, hanem a vérátömlesztés következtében kialakuló lehetséges szövődmények is rontják a betegek felépülési esélyeit. EVIAR-t követően szignifikánsan kevesebb esetben van szükség perioperatív transzfúzióra. Korábbi kutatások egyhangúan hasonlóan kedvező transzfúziós eredményekről számolnak be [7, 9, 12], ami endovascularis mütét végzése során a kisebb kiterjedésű műtétből és vérveszteségből, a mütéti hossz csökkenéséből, illetve az alacsonyabb mértékben fellépő posztoperatív vérzéses szövődményekből adódik.

A túlélés-analízis eredménye alapján az EVIAR-on átesett betegek kissé nagyobb arányban voltak életben a nyitott mútétre került betegekhez képest az 5 éves utánkövetési időszakot vizsgálva, azonban szignifikáns különbséget nem találtunk a csoportok között. Huang és $m$ tsai [17] az a. iliaca communis nyitott és endovascularis mütéti kezelését hasonlították össze, és eredményeik- ben 65\%-os túlélésről számoltak be, mely nem különbözött szignifikánsan a két csoport között. Rana és mtsai [13] az a. iliaca interna aneurysma miatt végzett nyitott és endovascularis mütéti eredmények összehasonlításakor $62 \%$-os 5 éves túlélést írtak le, és szintén nem találtak szignifikáns eltérést a csoportok között. Az irodalmi adatokkal megegyeznek saját eredményeink. Öt évet követően a különbség elvesztése a generalizált érbetegség és az aneurysma kialakulásához vezető alapbetegségek megléte miatt alakulhat ki, nem pedig az eltérő érsebészeti kezelés következményeként.

$\mathrm{Az}$ aneurysma ruptura a legsúlyosabb szövődményt jelenti az a. iliaca tágulatában szenvedő betegek esetében, mely potenciálisan életveszélyes állapot, és vitális mútéti indikációt képez. Ruptura esetén a betegek életkilátásai jelentős mértékben csökkennek, hiszen rövid időn belül súlyos akut anaemia, hypovolaemiás sokk alakulhat ki. Amennyiben a beteg nyitott mütétre kerül, a mélyen a kismedencében elhelyezkedő, nehezen megközelíthető mütéti terület sebésztechnikailag is jelentős kihívást jelent. Irodalmi adatok alapján az aneurysma ruptura mortalitása igen magas, 30-50\% közötti [1, 18]. Adataink szerint a 10 aneurysma ruptura miatt felvételre került betegből 3 beteg közvetlenül a posztoperatív időszakban meghalt, ami 30\%-os korai mortalitást jelent, és megegyezik az irodalomban korábban leírtakkal. A 3 beteg közül 1 betegnél végeztünk nyitott mútétet, aki az intenzív osztályon hunyt el septicaemia és keringési elégtelenség miatt. Egy betegnél a. iliaca interna aneurysma ruptura miatt embolisatio és Amplatzer záróeszköz behelyezése történt, majd később az intenzív osztályon akut myocardialis infarctus következtében veszítettük el. Mindössze egy 88 éves, számos kíséróbetegségben szenvedő betegnél végeztünk stentgraftbeültetést, aki a nyitott mütétbe nem egyezett bele, és végül keringési elégtelenség volt a halála közvetlen oka. Ebben az esetben idős kora, kísérőbetegségei és az aneurysma ruptura fennállása játszott szerepet elvesztésében. A rupturált a. iliaca aneurysma endovascularis kezelésének eredményességéról megoszlanak a vélemények. Az irodalom alapján elmondható, hogy ruptura esetén a nyitott mútétet választják előszeretettel az operáló sebészek. Patel és mtsai [9] vizsgálatában az említett 4 rupturált eset mindegyike nyitott mütétre került. Boules és mtsai [8] az izolált a. iliaca aneurysma endovascularis kezelését vizsgálták, és 45 fós beteganyagukban rupturált esetet nem említenek. Gyakran a ruptura következtében fellépő haemodinamikai instabilitás jelenti az endovascularis műtét kontraindikációját [19]. Ennek ellentmond Fossaceca és mtsai [20] közleménye, mely 12 rupturált a. iliaca aneurysmával kezelt beteg endovascularis mútétének perioperatív mortalitását 16,6\%-ra teszi, és $83,4 \%$-os szövődménymentes beavatkozást említ. Eredményeik szerint ruptura esetén - amennyiben a megfelelő személyi és technikai feltételek rendelkezésre állnak - az endovascularis beavatkozást elsőként választandó terápiás eszköz- 
nek javasolják, mely gyakorlott sebész esetén jelentősen csökkenti a mütéti időt, az aktív vérzés gyors kontrollját eredményezve.

\section{Következtetés}

Klinikánkon az a. iliaca aneurysma miatt kezelt betegcsoportot a férfipredominancia jellemzi, és a leggyakrabban a 7 . életévtizedben fordul elő, az a. iliaca communison izoláltan.

Ruptura következtében 30\%-os korai posztoperatív mortalitással kell számolni.

EVIAR esetén szignifikánsan kevesebb a posztoperatív szövődmény, az intenzív terápiás kezelés szükségessége és hossza, valamint a kórházban eltöltött posztoperatív napok száma és a transzfúziós igény. A hosszú távú túlélési arány lényeges különbséget nem mutatott.

Eredményeink alapján ajánljuk a stentgraft-implantációt az a. iliaca aneurysma kezelésére, mivel alacsonyabb mértékü mütéti megterhelést jelent a betegek számára, illetve kevesebb perioperatív szövődménnyel és rövidebb kórházi és intenzív osztályos tartózkodással jár.

Anyagi támogatás: A közlemény megírása, illetve a kapcsolódó kutatómunka anyagi támogatásban nem részesült.

Szerzői munkamegosztás: G. D.: A kutatómunka megtervezése, adatgyüjtés, adatelemzés, statisztikai számítás, a kézirat megírása. B. A.: Statisztikai elemzés. L. P.: Adatgyưjtés, adatelemzés. Sz. Z.: A kutatómunka megtervezése, adatelemzés, a kézirat megírása. A cikk végleges változatát valamennyi szerző elolvasta és jóváhagyta.

Érdekeltségek: A szerzőknek nincsenek érdekeltségeik.

\section{Irodalom}

[1] Richardson JW, Greenfield LJ. Natural history and management of iliac aneurysms. J Vasc Surg. 1988; 8: 165-171.

[2] Casana R, Nano G, Dalainas I, et al. Midterm experience with the endovascular treatment of isolated iliac aneurysms. Int Angiol. 2003; 22: 32-35.

[3] Krupski WC, Selzman CH, Floridia R, et al. Contemporary management of isolated iliac aneurysms. J Vasc Surg. 1998; 28: 1-11.

[4] Moll FL, Powell JT, Fraedrich G, et al. Management of abdominal aortic aneurysms clinical practice guidelines of the European
Society for Vascular Surgery. Eur J Vasc Endovasc Surg. 2011; 41(Suppl 1): 1-58.

[5] Levi N, Schroeder TV. Isolated iliac artery aneurysms. Eur J Vasc Endovasc Surg. 1998; 16: 342-344.

[6] Buckley CJ, Buckley SD. Technical tips for endovascular repair of common iliac artery aneurysms. Semin Vasc Surg. 2008; 21: 31-34.

[7] Chaer RA, Barbato JE, Lin SC, et al. Isolated iliac artery aneurysms: a contemporary comparison of endovascular and open repair. J Vasc Surg. 2008; 47: 708-713.

[8] Boules TN, Selzer F, Stanziale SF, et al. Endovascular management of isolated iliac artery aneurysms. J Vasc Surg. 2006; 44: 29-37.

[9] Patel NV, Long GW, Cheem ZF, et al. Open vs. endovascular repair of isolated iliac artery aneurysms: A 12 -year experience. J Vasc Surg. 2009; 49: 1147-1153.

[10] Laine MT, Björck M, Beiles CB, et al. Few internal iliac artery aneurysms rupture under $4 \mathrm{~cm}$. J Vasc Surg. 2017; 65: 76-81.

[11] Igari K, Kudo T, Toyofuku T, et al. Comparison between endovascular repair and open surgery for isolated iliac artery aneurysms. Surg Today $2015 ; 45: 290-296$.

[12] Pitoulias GA, Donas KP, Schulte S, et al. Isolated iliac artery aneurysms: endovascular versus open elective repair. J Vasc Surg. 2007; 46: 648-654.

[13] Rana MA, Kalra M, Oderich GS, et al. Outcomes of open and endovascular repair for ruptured and nonruptured internal iliac artery aneurysms. J Vasc Surg. 2014; 59: 634-644.

[14] Lawrence PF, Gazak C, Bhirangi L, et al. The epidemiology of surgically repaired aneurysms in the United States. J Vasc Surg. 1999; 30: 632-640.

[15] Ferreira J, Canedo A, Brandao D, et al. Isolated iliac artery aneurysms: six-year experience. Interact Cardiovasc Thorac Surg. 2010; 10: 245-248.

[16] Buck DB, Bensley RP, Darling J, et al. The effect of endovascular treatment on isolated iliac artery aneurysm treatment and mortality. J Vasc Surg. 2015; 62: 331-335.

[17] Huang Y, Gloviczki P, Duncan AA, et al. Common iliac artery aneurysm: expansion rate and results of open surgical and endovascular repair. J Vasc Surg. 2008; 47: 1203-1210.

[18] Sandhu RS, Pipinos II. Isolated iliac artery aneurysms. Semin Vasc Surg. 2005; 18(4): 209-215.

[19] Fossaceca R, Guzzardi G, Cerini P, et al. Endovascular treatment of ruptured abdominal aortic aneurysms: is now EVAR the first choice of treatment? Cardiovasc Intervent Radiol. 2014; 37: 1156-1164.

[20] Fossaceca R, Guzzardi G, Cerini P, et al. Isolated iliac artery aneurysms: a single-centre experience. Radiol Med. 2015; 120: $440-448$. 